\title{
Employment Medical Advisory Service
}

\author{
MARGARET GRACEY \\ Medical Services Division, Department of Employment
}

Doctors were first brought into formal association with employment problems in 1844. The Factories Act of that year permitted superintending inspectors of factories to appoint surgeons to certify that children starting work in textile factories had the appearance and development appropriate to the age of 9 years. Over the years the statutory duties of the certifying surgeons, who were later called appointed factory doctors, were extended. Since 1948, their most important duties have been the medical examination of all young persons entering factory employment and annually thereafter up to the age of 18 , and the statutory medical examinations of persons working in hazardous trades.

There are some 1500 appointed factory doctors who are normally general practitioners carrying out these duties on a fee-for-service basis paid by the occupier. The first Medical Inspector of Factories was appointed in 1898 and by 1970 there was a medical inspector in each division of the Factory Inspectorate together with a senior medical inspector and his staff at headquarters, a total of 22 full-time doctors.

In 1964 the Industrial Health Advisory Committee, which advises the Secretary of State on industrial health matters, decided to review the Appointed Factory Doctor (AFD) service. The Confederation of British Industry, the Trades Union Congress, the British Medical Association, and other medical interests were represented on the Sub-committee which was set up and whose unanimous report, which was published in 1966, recommended radical changes in the duties of AFDs. In particular, they advised that:

(a) the routine medical examinations of young persons under the Factories Act should be abandoned in favour of a more selective system concentrating on those young persons in need of medical advice, and

(b) the 1500 AFDs with their narrow range of statutory duties should be replaced by a much smaller number of doctors with a wider range of duties and more expertise in occupational health matters.

The Sub-committee's recommendations were accepted by the Minister of Labour and after further discussion it was agreed that the new medical service should be advisory to the whole of the Department of Employment on any medical problem relating to employment. A Bill to make the necessary legislative changes was introduced in 1969 as Part I of the Employed Persons (Health and Safety) Bill. It had, however, only reached the Standing Committee when Parliament was dissolved before the general election of June 1970 and so the Bill automatically lapsed.

Nevertheless, administrative action continued within the Department to co-ordinate the work of its various medical services. These were the Medical Inspectors of Factories, the medical services to Industrial Rehabilitation Units and Government Training Centres, and the Regional Medical Consultants - a total of 23 full-time and 58 part-time doctors. The Medical Services Division was established in the Department in December 1970 and the Senior Medical Inspector of Factories, Dr. T. A. Lloyd Davies, became Chief Medical Adviser with professional oversight of the work of the other doctors employed in the Department. At the same time the Medical Branch was separated from the Factory Inspectorate, the Medical Inspectors of Factories becoming Medical Advisers. As a result of these changes the Medical Advisers of the newly created Medical Services Division extended their work beyond the confines of the Factories Act and, so far as their limited staffing resources permitted, gave advice to other divisions on a wide range of medical problems related to employment.

In November 1971 Part I of the Employed Persons (Health and Safety) Bill was re-introduced as the Employment Medical Advisory Service Bill and received Royal Assent on 11 May 1972. The Act will come into operation on 1 February 1973.

In the words of the Act, the Employment Medical 
Advisory Service will ensure that 'the Secretary of State and others concerned with the health of employed persons and of persons training for employment can be kept informed of and adequately advised on matters of which they ought respectively to take cognizance concerning the safe-guarding and improvement of the health of those persons'. The duties of the Employment Medical Advisers, which will include the existing work of the Medical Services Division and some of the work formerly carried out by AFDs, can be summarized under the following headings:

(a) Advice to young people and their parents, careers officers, and school medical officers on the medical aspects of the employment of young people;

(b) the medical examination and follow-up of young persons entering employment who are identified by the School Health Service as being in need of medical supervision;

(c) advice to employers, trade unions, employees, and others concerned about medical matters related to work;

(d) study of health hazards in factories and advice to HM Factory Inspectorate;

(e) medical examination of persons employed on particular hazardous processes subject to regulations under the Factories Act;

$(f)$ carrying out medical examinations, investigations, and surveys of workers in connection with their employment;

(g) liaison with general practitioners, hospital staff, works medical officers, and others interested in occupational medicine;

(h) medical advice to general practitioners in connection with their patients' work;

(i) co-operation with the Department of Employment's placing, training, and disablement resettlement services; and

$(j)$ medical supervision, medical guidance, and medical examination of those attending Government Training Centres and Industrial Rehabilitation Units.

Most of these duties are self-explanatory but it might be helpful to enlarge a little on the special responsibility of the Employment Medical Advisory Service (EMAS) towards young persons. At present, the School Health Service identifies, from records or by means of interview or examination, school leavers who are not unconditionally fit for all types of employment and notifies the Careers Officer of the Youth Employment Service on a standard form. In future, the School Health Service will also send a copy of this standard form to the Employment Medical Adviser (EMA) and to the general practitioner. The form does not contain any medical details but gives advice in simple terms on the types of work or working conditions that the school leaver should avoid, such as working at heights or carrying heavy weights. It will then be possible for the Careers Officer and the EMA to consult during the whole process of advising these school-leavers and placing them in employment. When a young person enters employment covered by the Factories Act the employer must notify the Careers Officer within seven days. This will enable EMAs and Careers Officers to keep a particular watch on those young people in factory employment who may need further medical supervision. The EMA will also advise any other young persons needing medical advice about their employment problems and he will work closely with the disablement resettlement officer in dealing with handicapped young people.

In order to carry out their duties freely EMAs will be able to enter a factory, require the production of registers, and require factory occupiers to permit a workman to attend for medical examination. These powers will, however, be kept very much in the background: the main work of the EMAS will be advisory, as its name implies.

The medical examinations carried out by the EMAs may include pathological, physiological, and radiological investigations. To help in this, the medical laboratory of the Medical Services Division is being expanded as a central reference laboratory where special attention will be paid to the development of biological tests of exposure and response to toxic substances. In addition, the EMAS will be able to call on the facilities of the National Health Service, such as laboratory and radiological services. Professional statistical advice together with a special information service on occupational medicine will be available to the EMAS.

Apart from the medical examinations carried out under the Factories Act and Regulations, for which the occupier will continue to pay, the services of the EMAS will be free of charge to the occupier and the worker.

When it is fully operational the EMAS will employ about 120 doctors, of whom approximately twothirds will be full-time. In addition, there will be a number of nurses and supporting administrative and secretarial staff. There will be the Chief Employment Medical Adviser and a small supporting staff at Headquarters and a Regional Employment Medical Adviser at the head of the team of EMAs in each region.

In May 1970, when the Employed Persons (Health and Safety) Bill was before Parliament, the Committee on Safety and Health under the chairmanship of Lord Robens was set up. The Robens Committee therefore knew of the proposals relating to the EMAS in the Employed Persons (Health and Safety) Bill but, before the legislation was reintroduced in November 1971, Lord Robens was asked for his 
views. He said he saw this as a constructive measure which would prejudice neither his Committee's recommendations on safety and health nor possible further development of occupational medicine within the context of the general health services. This view is restated in Chapter 12 of the Robens Committee Report, Safety and Health at Work (1972), which welcomes the EMAS as being in harmony with its own general philosophy and as a carefully planned step forward in the development of occupational medicine.

During the debates in Parliament on the EMAS Bill, and in correspondence with the various interested organizations, Ministers have stressed that to be a success the new service must work in close cooperation with existing medical services, both government and private.

The close liaison between the EMAS and the School Health Service has already been mentioned. It will also work closely with the National Health Service, the joint use of laboratory facilities being an important means of strengthening this collaboration. As regards private works medical services, the existing arrangements whereby works medical officers can be appointed to carry out statutory medical examinations will continue.
The EMAS will be a small expert advisory service which it is hoped will be a focus for the development of occupational medicine in this country. As a national service it can carry out the epidemiological surveys which are essential for identifying health hazards in industry, particularly those connected with new materials and processes. It will organize an adequate system of medical monitoring by both statutory and voluntary medical examinations in industry. It will not only deal with industrial diseases in the narrow sense but will study man's response to requirements imposed by work and will seek to identify and elucidate the new tensions arising from modern technological society. It should thus help in the placement of men and women in the right work so that they may use their skills happily and efficiently, and once they are in work be better protected from both the mental and physical hazards of their working environment.

\section{Reference}

Safety and Health at Work (1972). Report of the Committee 1970-72. Chairman, Lord Robens. Cmnd. 5034. H.M.S.O., London.

Received for publication October 5, 1972. 